\title{
ReumaCoV Brasil Registry: Brazilian Study of Patients with Immuno-mediated Chronic Inflammatory Diseases Infected by SARS-CoV-2
}

Claudia Diniz Lopes Marques ( $\sim$ claudia.reumatologia@gmail.com )

UFPE https://orcid.org/0000-0002-3333-2621

Adriana Maria Kakehasi

UFME

Ana Paula Monteiro Gomides

UnB

Danyelly Bruneska Gondim Martins

LIKA

Eduardo dos Santos Paiva

UFPR

Edgard Torres dos Reis Neto

UNIFESP

Gecilmara Cristina Salviato Pileggi

Faculdade de Ciências da Saúde de Barretos (FACISB) - São Paulo

Gilda Aparecida Ferreira

UFMG

Licia Maria Henrique da Mota

UnB

Marcelo Medeiros Pinheiro

UNIFESP

Ricardo Machado Xavier

UFRGS

José Roberto Provenza

PUCCAMP

\section{Method Article}

Keywords: COVID-19, SARS-CoV-2, prospective cohort, Immune-mediated rheumatic diseases, registry

Posted Date: September 5th, 2020

DOI: https://doi.org/10.21203/rs.3.pex-1104/v1 
License: (c) (i) This work is licensed under a Creative Commons Attribution 4.0 International License. Read Full License 


\section{Abstract}

Patients with immune-mediated rheumatic diseases (IMRD) are at increased risk of infections, including significant morbidity and high mortality. Considering the potential for unfavorable outcomes of SARSCoV-2 infection in patients with IMRD, a huge number of questions were released regarding the impact of COVID-19 in the beginning of the pandemic. Seeking to better understand this complex interaction, this study was developed to evaluate prospectively patients with IMRD and a suspected or confirmed COVID19 diagnosis, according to the Ministry of Health of Brazil's definitions. The primary outcomes will be the IMRD disease activity changes after COVID-19, at four time points: (1) At baseline and prior 6 months; (2) The first rheumatic evaluation after known infection by SARS-CoV-2 (4-6 weeks); (3) 3 months after the inclusion ( \pm 15 days); (4) 6 months after inclusion ( \pm 15 days). The secondary outcomes will be the progression rate to severe forms of COVID-19, need for intensive care unit admission and mechanical ventilation, death and therapeutic changes related to the IMRD. Two outcomes are of particular interest considering the COVID-19 in IMRD patients, namely pulmonary and the thromboembolic events, and they will be monitored with more attention and details (clinical, lab, function tests and imaging). This protocol was approved by the Brazilian Committee of Ethics in Human Research (CONEP) on April $5^{\text {th }}, 2020$ (CAAE 30186820.2.1001.8807; Number: 3.933.204) and registered on the Brazilian Registry of Clinical Trials REBEC (RBR-33YTQC) in June, $1^{\text {st }} 2020$. We believe this study will provide many clinically relevant data on the general impact of COVID-19 on IMRD patients.

\section{Introduction}

The Coronavirus Disease (COVID-19) was declared as pandemic in March, $11^{\text {th }}, 2020$ by World Health Organization (WHO) [1] and Brazil was the first Latin American country to have a confirmed case of COVID-19 in February $26^{\text {th }}, 2020$ [2]. Heretofore, almost 3 millions of cases and more than 90,000 deaths have been confirmed in our country by July, $31^{\text {th }} 2020$ [3].

Patients with immune-mediated rheumatic diseases (IMRD) are at increased risk of infections, including significant morbidity and high mortality[4]. It is worthy emphasizing this is a complex binomial with many factors involved, such as disease activity, age, comorbidities and drugs, such as glucocorticoids (GCs), conventional synthetic, specific target or biological disease-modifying anti-rheumatic drugs (csDMARD, stDMARD or bioDMARD, respectively) and immunosuppressants [5]. Considering a possibly poorer evolution of SARS-CoV-2 infection in patients with IMRD, a large amount of questions have been posed regarding the impact of COVID-19 in the beginning of the pandemic, including withdrawal or spacing of medications, hospitalization, need of mechanical ventilation and mortality rate [6-8].

With the evidences moving forward, some Italian, American, French and Chinese databases have started to demonstrate that the risk of bad/poor outcome is quite similar to general population and could be more related to comorbidities and aging than IMRD itself [9-11]. However, there are controversial data, especially regarding the mortality rates [12]. 
Considering Brazil as a continental country and with relevant regional and socioeconomic differences, as well as discrepancies concerning basic sanitation and access to the public and private health care systems, it is important to address the incidence, peculiarities related to disease activity and drug management, and survival curve in IMRD patients with COVID-19.

\section{Reagents}

\section{Equipment}

\section{Procedure}

This paper shows details of the protocol design for the Brazilian Registry of Patients with Immunomediated Chronic Inflammatory Diseases Infected by Sars-Cov-2 (ReumaCoV-Brasil) (Brazilian Register of

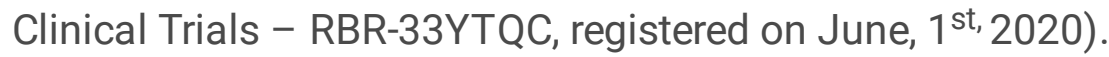

1. Data collection began in May 2020, using a convenience sampling strategy.

2. The data will be collected at three distinct periods: inclusion, 3 months, and 6 months. Participating centers were selected based on their expressed interest after a collective invitation had been sent to all rheumatologists affiliated to the Brazilian Society of Rheumatology. Most of them are public reference centers involved in teaching and forming fellows in rheumatology, but some have focus in private care.

3. Regardless COVID-19 diagnosis, the eligible patients include those aged 18 years or over with prior diagnosis of IMRD, according to the American College of Rheumatology (ACR) or European League against Rheumatism (EULAR) criteria, including rheumatoid arthritis (RA)[14, 15], systemic lupus erythematosus (SLE)[16, 17], Sjögren's syndrome (SS)[18], systemic sclerosis (ES)[19], inflammatory myopathies[20], axial spondyloarthritis[21-23], enteropathic arthritis[24], psoriatic arthritis[25] sarcoidosis[26], antiphospholipid syndrome (APS)[27], Behçet disease [28], mixed connective tissue disease[29], Takayasu arteritis[30, 31], giant cell arteritis[32], ANCA-associated vasculitides[33-36] and juvenile idiopathic arthritis at adult age [37].

4. The exclusion criteria were other immunodeficiency diseases, past organ or bone marrow transplantation, neoplasms within the last five years, current chemotherapy, HIV diagnosis and thymus diseases. The controls (not exposed) will be patients with IMRD without suggestive symptoms or diagnosis of COVID-19, matched for sex, age and IMRD, respecting the same exclusion criteria.

5. Cases (exposed) and controls (non exposed) will be enrolled after reading and signing the informed consent (ICF - Appendix A). 
6. The clinical form (Appendix B) will be filled at baseline and 3- and 6-month follow-up using the REDCAp platform.

7. A total of $14 \mathrm{~mL}$ of blood will be collected for further lab exams, according to the protocol described at figure 3 .

8. The blood will be centrifuged at $3000 \mathrm{rpm}$ with serum being separated and stored at $-20^{\circ} \mathrm{C}$ in each participating center and it will be sent to the Hermes Pardini Laboratory posteriorly in a one-way shipping.

9. The anti-SARS-CoV-2 antibodies (IgM and IgG) will be evaluated by ELISA (Euroimmun ${ }^{\circledR}$ ), using plasma aliquots, according to the manufacturer's recommendations. Rheumatoid factor, anti-CCP, ANA, anticardiolipin ( $\lg G$ and $\lg M$ ) and immunoglobulins ( $\lg M$, $\lg G$ and $\lg A$ ) will be tested using serum aliquots, using pre-established protocols.

10. The total blood and another one tube that the RNAlater was added will be shipped to the LIKA (Keizo Asami Immunopathology Laboratory), located at Federal University of Pernambuco (UFPE) and maintained at $-80 \mathrm{oC}$ until the genetic and epigenetics evaluation.

11. The primary outcomes will be the IMRD disease activity changes after COVID-19, at four time points: (1) At baseline or recording data in the last 6 months; (2) The first rheumatic evaluation after COVID-19 (4-6 weeks); (3) 3 months after the inclusion ( \pm 15 days); (4) 6 months after inclusion ( \pm 15 days) (Table 2).

12. Details about previous lab exams will also be recorded, such as ESR, CRP, rheumatoid factor, anti-CCP, ANA, anti-ENA, anti-double-stranded-DNA, HLA-B27, complement, anticardiolipin IgG and IgM, ANCA and cryoglobulins.

\section{Troubleshooting}

\section{Time Taken}

\section{Anticipated Results}

\section{References}

\section{REFERENCES}


1. WHO. Coronavirus Diseases 2019 (COVID-19) situation report - 51 2020. Available from: https://www.who.int/docs/default-source/coronaviruse/situation-reports/20200311-sitrep-51-covid19.pdf?sfvrsn=1ba62e57_10.

2. Candido DS, Claro IM, de Jesus JG, Souza WM, Moreira FRR, Dellicour S, et al. Evolution and epidemic spread of SARS-CoV-2 in Brazil. Science. 2020:eabd2161. doi: 10.1126/science.abd2161.

3. Medicine JHUo. Coronavirus Resource Center 2020 [cited 2020 Jun, 24th]. Available from: https://coronavirus.jhu.edu/map.html.

4. Gabriel SE, Michaud K. Epidemiological studies in incidence, prevalence, mortality, and comorbidity of the rheumatic diseases. Arthritis Res Ther. 2009;11(3):229. Epub 2009/06/13. doi: 10.1186/ar2669. PubMed PMID: 19519924; PubMed Central PMCID: PMCPMC2714099.

5. Falagas ME, Manta KG, Betsi GI, Pappas G. Infection-related morbidity and mortality in patients with connective tissue diseases: a systematic review. Clin Rheumatol. 2007;26(5):663-70. Epub 2006/12/23. doi: 10.1007/s10067-006-0441-9. PubMed PMID: 17186117.

6. Antony A, Connelly K, De Silva T, Eades L, Tillett W, Ayoub S, et al. Perspectives of patients with rheumatic diseases in the early phase of COVID-19. Arthritis Care Res (Hoboken). 2020. Epub 2020/06/12. doi: 10.1002/acr.24347. PubMed PMID: 32526068; PubMed Central PMCID: PMCPMC7300883.

7. Landewe RB, Machado PM, Kroon F, Bijlsma HW, Burmester GR, Carmona L, et al. EULAR provisional recommendations for the management of rheumatic and musculoskeletal diseases in the context of SARS-CoV-2. Ann Rheum Dis. 2020;79(7):851-8. Epub 2020/06/07. doi: 10.1136/annrheumdis2020-217877. PubMed PMID: 32503854.

8. Michaud K, Wipfler K, Shaw Y, Simon TA, Cornish A, England BR, et al. Experiences of Patients With Rheumatic Diseases in the United States During Early Days of the COVID-19 Pandemic. ACR Open Rheumatol. 2020;2(6):335-43. Epub 2020/04/21. doi: 10.1002/acr2.11148. PubMed PMID: 32311836; PubMed Central PMCID: PMCPMC7264613.

9. Favalli EG, Ingegnoli F, De Lucia O, Cincinelli G, Cimaz R, Caporali R. COVID-19 infection and rheumatoid arthritis: Faraway, so close! Autoimmun Rev. 2020;19(5):102523. Epub 2020/03/25. doi: 10.1016/j.autrev.2020.102523. PubMed PMID: 32205186; PubMed Central PMCID: PMCPMC7102591.

10. Figueroa-Parra G, Aguirre-Garcia GM, Gamboa-Alonso CM, Camacho-Ortiz A, Galarza-Delgado DA. Are my patients with rheumatic diseases at higher risk of COVID-19? Ann Rheum Dis. 2020;79(6):839-40. Epub 2020/03/25. doi: 10.1136/annrheumdis-2020-217322. PubMed PMID: 32205336.

11. Lu C, Li S, Liu Y. Role of immunosuppressive therapy in rheumatic diseases concurrent with COVID19. Ann Rheum Dis. 2020;79(6):737-9. Epub 2020/04/17. doi: 10.1136/annrheumdis-2020-217460. 
PubMed PMID: 32295789.

12. Marques C, Pinheiro MM, Reis Neto ET, Dantas AT, Ribeiro FM, Melo AKG. COVID-19 in patients with rheumatic diseases: what is the real mortality risk? Ann Rheum Dis. 2020. Epub 2020/07/15. doi: 10.1136/annrheumdis-2020-218388. PubMed PMID: 32660978.

13. Brasil. COVID-19. Definição de caso e notificação: Ministério da Saúde; 2020 [cited 2020 27, July]. Available from: https://coronavirus.saude.gov.br/index.php/definicao-de-caso-e-notificacao.

14. Aletaha D, Neogi T, Silman AJ, Funovits J, Felson DT, Bingham CO, 3rd, et al. 2010 rheumatoid arthritis classification criteria: an American College of Rheumatology/European League Against Rheumatism collaborative initiative. Ann Rheum Dis. 2010;69(9):1580-8. Epub 2010/08/12. doi: 10.1136/ard.2010.138461. PubMed PMID: 20699241.

15. Arnett FC, Edworthy SM, Bloch DA, McShane DJ, Fries JF, Cooper NS, et al. The American Rheumatism Association 1987 revised criteria for the classification of rheumatoid arthritis. Arthritis Rheum. 1988;31(3):315-24. Epub 1988/03/01. doi: 10.1002/art.1780310302. PubMed PMID: 3358796.

16. Hochberg MC. Updating the American College of Rheumatology revised criteria for the classification of systemic lupus erythematosus. Arthritis Rheum. 1997;40(9):1725. Epub 1997/10/27. doi: 10.1002/art.1780400928. PubMed PMID: 9324032.

17. Petri M, Orbai AM, Alarcon GS, Gordon C, Merrill JT, Fortin PR, et al. Derivation and validation of the Systemic Lupus International Collaborating Clinics classification criteria for systemic lupus erythematosus. Arthritis Rheum. 2012;64(8):2677-86. Epub 2012/05/04. doi: 10.1002/art.34473. PubMed PMID: 22553077; PubMed Central PMCID: PMCPMC3409311.

18. Shiboski SC, Shiboski CH, Criswell L, Baer A, Challacombe S, Lanfranchi H, et al. American College of Rheumatology classification criteria for Sjogren's syndrome: a data-driven, expert consensus approach in the Sjogren's International Collaborative Clinical Alliance cohort. Arthritis Care Res (Hoboken). 2012;64(4):475-87. Epub 2012/05/09. doi: 10.1002/acr.21591. PubMed PMID: 22563590; PubMed Central PMCID: PMCPMC3349440.

19. van den Hoogen F, Khanna D, Fransen J, Johnson SR, Baron M, Tyndall A, et al. 2013 classification criteria for systemic sclerosis: an American College of Rheumatology/European League against Rheumatism collaborative initiative. Arthritis Rheum. 2013;65(11):2737-47. Epub 2013/10/15. doi: 10.1002/art.38098. PubMed PMID: 24122180; PubMed Central PMCID: PMCPMC3930146.

20. Lundberg IE, Tjarnlund A, Bottai M, Werth VP, Pilkington C, Visser M, et al. 2017 European League Against Rheumatism/American College of Rheumatology classification criteria for adult and juvenile idiopathic inflammatory myopathies and their major subgroups. Ann Rheum Dis. 2017;76(12):1955-64. Epub 2017/10/29. doi: 10.1136/annrheumdis-2017-211468. PubMed PMID: 29079590; PubMed Central PMCID: PMCPMC5736307. 
21. Rudwaleit M, van der Heijde D, Landewe R, Akkoc N, Brandt J, Chou CT, et al. The Assessment of SpondyloArthritis International Society classification criteria for peripheral spondyloarthritis and for spondyloarthritis in general. Ann Rheum Dis. 2011;70(1):25-31. Epub 2010/11/27. doi: 10.1136/ard.2010.133645. PubMed PMID: 21109520.

22. Rudwaleit M, van der Heijde D, Landewe R, Listing J, Akkoc N, Brandt J, et al. The development of Assessment of SpondyloArthritis international Society classification criteria for axial spondyloarthritis (part II): validation and final selection. Ann Rheum Dis. 2009;68(6):777-83. Epub 2009/03/20. doi: 10.1136/ard.2009.108233. PubMed PMID: 19297344.

23. van der Linden S, Valkenburg HA, Cats A. Evaluation of diagnostic criteria for ankylosing spondylitis. A proposal for modification of the New York criteria. Arthritis Rheum. 1984;27(4):361-8. Epub 1984/04/01. doi: 10.1002/art.1780270401. PubMed PMID: 6231933.

24. Orchard TR, Wordsworth BP, Jewell DP. Peripheral arthropathies in inflammatory bowel disease: their articular distribution and natural history. Gut. 1998;42(3):387-91. Epub 1998/05/13. doi: 10.1136/gut.42.3.387. PubMed PMID: 9577346; PubMed Central PMCID: PMCPMC1727027.

25. Taylor W, Gladman D, Helliwell P, Marchesoni A, Mease P, Mielants $\mathrm{H}$, et al. Classification criteria for psoriatic arthritis: development of new criteria from a large international study. Arthritis Rheum. 2006;54(8):2665-73. Epub 2006/07/28. doi: 10.1002/art.21972. PubMed PMID: 16871531.

26. Heinle R, Chang C. Diagnostic criteria for sarcoidosis. Autoimmun Rev. 2014;13(4-5):383-7. Epub 2014/01/16. doi: 10.1016/j.autrev.2014.01.035. PubMed PMID: 24424172.

27. Miyakis S, Lockshin MD, Atsumi T, Branch DW, Brey RL, Cervera R, et al. International consensus statement on an update of the classification criteria for definite antiphospholipid syndrome (APS). J Thromb Haemost. 2006;4(2):295-306. Epub 2006/01/20. doi: 10.1111/j.1538-7836.2006.01753.x. PubMed PMID: 16420554.

28. International Team for the Revision of the International Criteria for Behcet's D. The International Criteria for Behcet's Disease (ICBD): a collaborative study of 27 countries on the sensitivity and specificity of the new criteria. J Eur Acad Dermatol Venereol. 2014;28(3):338-47. Epub 2013/02/28. doi: 10.1111/jdv.12107. PubMed PMID: 23441863.

29. Kasukawa R. Mixed connective tissue disease. Intern Med. 1999;38(5):386-93. Epub 1999/07/09. doi: 10.2169/internalmedicine.38.386. PubMed PMID: 10397074.

30. Arend WP, Michel BA, Bloch DA, Hunder GG, Calabrese LH, Edworthy SM, et al. The American College of Rheumatology 1990 criteria for the classification of Takayasu arteritis. Arthritis Rheum. 1990;33(8):1129-34. Epub 1990/08/11. doi: 10.1002/art.1780330811. PubMed PMID: 1975175. 
31. Sharma BK, Jain S, Suri S, Numano F. Diagnostic criteria for Takayasu arteritis. Int J Cardiol. 1996;54 Suppl:S141-7. Epub 1997/08/01. doi: 10.1016/s0167-5273(96)88783-3. PubMed PMID: 9119516.

32. Hunder GG, Bloch DA, Michel BA, Stevens MB, Arend WP, Calabrese LH, et al. The American College of Rheumatology 1990 criteria for the classification of giant cell arteritis. Arthritis Rheum. 1990;33(8):1122-8. Epub 1990/08/01. doi: 10.1002/art.1780330810. PubMed PMID: 2202311.

33. Watts R, Lane S, Hanslik T, Hauser T, Hellmich B, Koldingsnes W, et al. Development and validation of a consensus methodology for the classification of the ANCA-associated vasculitides and polyarteritis nodosa for epidemiological studies. Ann Rheum Dis. 2007;66(2):222-7. Epub 2006/08/12. doi: 10.1136/ard.2006.054593. PubMed PMID: 16901958; PubMed Central PMCID: PMCPMC1798520.

34. Lightfoot RW, Jr., Michel BA, Bloch DA, Hunder GG, Zvaifler NJ, McShane DJ, et al. The American College of Rheumatology 1990 criteria for the classification of polyarteritis nodosa. Arthritis Rheum. 1990;33(8):1088-93. Epub 1990/08/11. doi: 10.1002/art.1780330805. PubMed PMID: 1975174.

35. Leavitt RY, Fauci AS, Bloch DA, Michel BA, Hunder GG, Arend WP, et al. The American College of Rheumatology 1990 criteria for the classification of Wegener's granulomatosis. Arthritis Rheum. 1990;33(8):1101-7. Epub 1990/08/01. doi: 10.1002/art.1780330807. PubMed PMID: 2202308.

36. Masi AT, Hunder GG, Lie JT, Michel BA, Bloch DA, Arend WP, et al. The American College of Rheumatology 1990 criteria for the classification of Churg-Strauss syndrome (allergic granulomatosis and angiitis). Arthritis Rheum. 1990;33(8):1094-100. Epub 1990/08/01. doi: 10.1002/art.1780330806. PubMed PMID: 2202307.

37. Martini A, Ravelli A, Avcin T, Beresford MW, Burgos-Vargas R, Cuttica R, et al. Toward New Classification Criteria for Juvenile Idiopathic Arthritis: First Steps, Pediatric Rheumatology International Trials Organization International Consensus. J Rheumatol. 2019;46(2):190-7. Epub 2018/10/03. doi: 10.3899/jrheum.180168. PubMed PMID: 30275259.

38. Finak G, Langweiler M, Jaimes M, Malek M, Taghiyar J, Korin Y, et al. Standardizing Flow Cytometry Immunophenotyping Analysis from the Human ImmunoPhenotyping Consortium. Sci Rep. 2016;6:20686. Epub 2016/02/11. doi: 10.1038/srep20686. PubMed PMID: 26861911; PubMed Central PMCID: PMCPMC4748244.

39. Mathew D, Giles JR, Baxter AE, Greenplate AR, Wu JE, Alanio C, et al. Deep immune profiling of COVID-19 patients reveals patient heterogeneity and distinct immunotypes with implications for therapeutic interventions. bioRxiv. 2020. Epub 2020/06/09. doi: 10.1101/2020.05.20.106401. PubMed PMID: 32511371; PubMed Central PMCID: PMCPMC7263500.

40. Blanco-Melo D, Nilsson-Payant BE, Liu WC, Uhl S, Hoagland D, Moller R, et al. Imbalanced Host Response to SARS-CoV-2 Drives Development of COVID-19. Cell. 2020;181(5):1036-45 e9. Epub 
2020/05/18. doi: 10.1016/j.cell.2020.04.026. PubMed PMID: 32416070; PubMed Central PMCID: PMCPMC7227586.

41. World Medical A. World Medical Association Declaration of Helsinki: ethical principles for medical research involving human subjects. JAMA. 2013;310(20):2191-4. Epub 2013/10/22. doi:

10.1001/jama.2013.281053. PubMed PMID: 24141714.

42. Smolen JS, Aletaha D. Scores for all seasons: SDAI and CDAl. Clin Exp Rheumatol. 2014;32(5 Suppl 85):S-75-9. Epub 2014/11/05. PubMed PMID: 25365093.

43. Machado PM, Landewe R, Heijde DV, Assessment of SpondyloArthritis international S. Ankylosing Spondylitis Disease Activity Score (ASDAS): 2018 update of the nomenclature for disease activity states. Ann Rheum Dis. 2018;77(10):1539-40. Epub 2018/02/18. doi: 10.1136/annrheumdis-2018-213184. PubMed PMID: 29453216.

44. Garrett S, Jenkinson T, Kennedy LG, Whitelock H, Gaisford P, Calin A. A new approach to defining disease status in ankylosing spondylitis: the Bath Ankylosing Spondylitis Disease Activity Index. J Rheumatol. 1994;21(12):2286-91. Epub 1994/12/01. PubMed PMID: 7699630.

45. Langley RG, Ellis CN. Evaluating psoriasis with Psoriasis Area and Severity Index, Psoriasis Global Assessment, and Lattice System Physician's Global Assessment. J Am Acad Dermatol. 2004;51(4):563-9. Epub 2004/09/25. doi: 10.1016/j.jaad.2004.04.012. PubMed PMID: 15389191.

46. Eberl G, Studnicka-Benke A, Hitzelhammer H, Gschnait F, Smolen JS. Development of a disease activity index for the assessment of reactive arthritis (DAREA). Rheumatology (Oxford). 2000;39(2):14855. Epub 2000/03/21. doi: 10.1093/rheumatology/39.2.148. PubMed PMID: 10725064.

47. Coates LC, Fransen J, Helliwell PS. Defining minimal disease activity in psoriatic arthritis: a proposed objective target for treatment. Ann Rheum Dis. 2010;69(1):48-53. Epub 2009/01/17. doi: 10.1136/ard.2008.102053. PubMed PMID: 19147615.

48. Gladman DD, Ibañez D, Urowitz MB. Systemic lupus erythematosus disease activity index 2000. J Rheumatol. 2002;29(2):288-91. Epub 2002/02/13. PubMed PMID: 11838846.

49. Uribe AG, Vilá LM, McGwin G, Jr., Sanchez ML, Reveille JD, Alarcón GS. The Systemic Lupus Activity Measure-revised, the Mexican Systemic Lupus Erythematosus Disease Activity Index (SLEDAI), and a modified SLEDAI-2K are adequate instruments to measure disease activity in systemic lupus erythematosus. J Rheumatol. 2004;31(10):1934-40. Epub 2004/10/07. PubMed PMID: 15468356.

50. Seror R, Bowman SJ, Brito-Zeron P, Theander E, Bootsma H, Tzioufas A, et al. EULAR Sjogren's syndrome disease activity index (ESSDAI): a user guide. RMD Open. 2015;1(1):e000022. Epub 2015/10/29. doi: 10.1136/rmdopen-2014-000022. PubMed PMID: 26509054; PubMed Central PMCID: PMCPMC4613159. 
51. Khanna D, Merkel PA. Outcome measures in systemic sclerosis: an update on instruments and current research. Curr Rheumatol Rep. 2007;9(2):151-7. Epub 2007/05/16. doi: 10.1007/s11926-0070010-5. PubMed PMID: 17502046.

52. Neves FS, Moraes JC, Kowalski SC, Goldenstein-Schainberg C, Lage LV, Goncalves CR. Crosscultural adaptation of the Behcet's Disease Current Activity Form (BDCAF) to Brazilian Portuguese language. Clin Rheumatol. 2007;26(8):1263-7. Epub 2006/12/21. doi: 10.1007/s10067-006-0484-y. PubMed PMID: 17180637.

53. Baschung Pfister P, de Bruin ED, Sterkele I, Maurer B, de Bie RA, Knols RH. Manual muscle testing and hand-held dynamometry in people with inflammatory myopathy: An intra- and interrater reliability and validity study. PLoS One. 2018;13(3):e0194531. Epub 2018/03/30. doi:

10.1371/journal.pone.0194531. PubMed PMID: 29596450; PubMed Central PMCID: PMCPMC5875759.

54. Fries JF, Spitz P, Kraines RG, Holman HR. Measurement of patient outcome in arthritis. Arthritis Rheum. 1980;23(2):137-45. Epub 1980/02/01. doi: 10.1002/art.1780230202. PubMed PMID: 7362664.

55. Luqmani RA, Bacon PA, Moots RJ, Janssen BA, Pall A, Emery P, et al. Birmingham Vasculitis Activity Score (BVAS) in systemic necrotizing vasculitis. Qjm. 1994;87(11):671-8. Epub 1994/11/01. PubMed PMID: 7820541.

56. Guillevin L, Lhote F, Gayraud M, Cohen P, Jarrousse B, Lortholary O, et al. Prognostic factors in polyarteritis nodosa and Churg-Strauss syndrome. A prospective study in 342 patients. Medicine (Baltimore). 1996;75(1):17-28. Epub 1996/01/01. doi: 10.1097/00005792-199601000-00003. PubMed PMID: 8569467.

\section{Acknowledgements}

We thank the researchers involved in the 43 centers participating in the protocol.

\section{Figures}




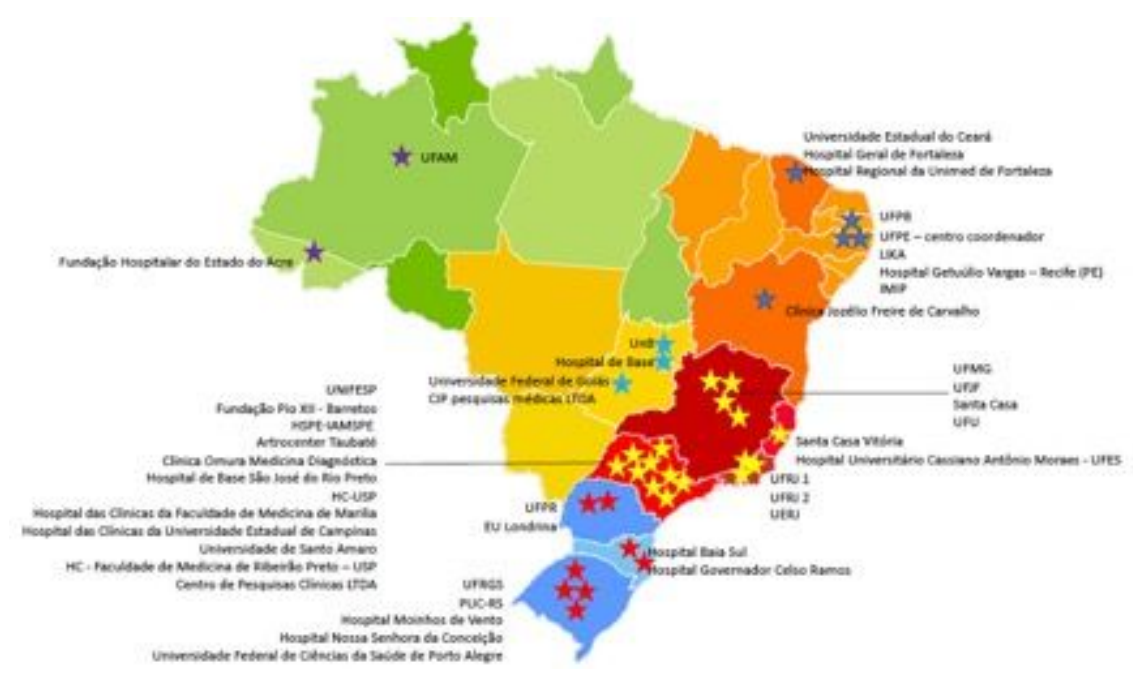

\section{Figure 1}

Mapping of 43 centers spread in five geographic regions of the country

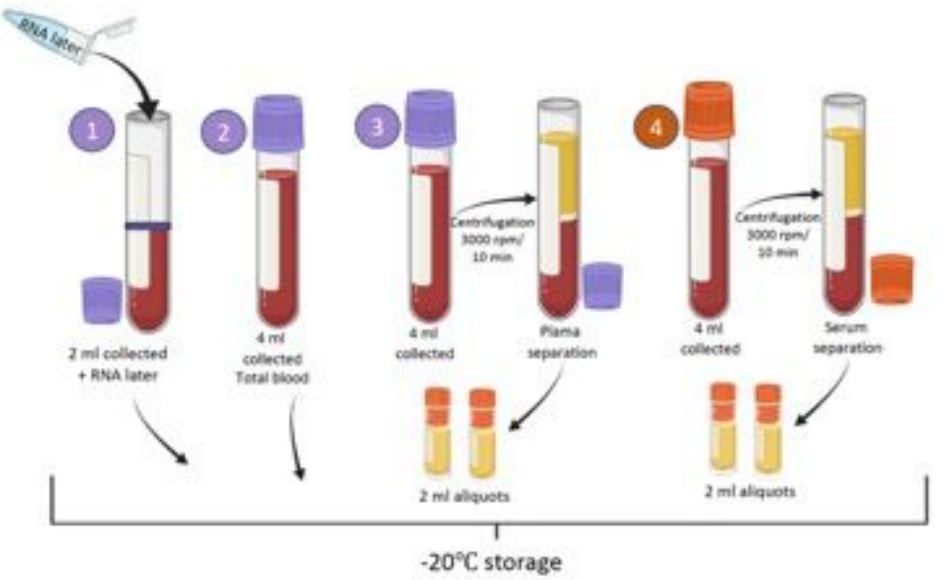

Figure 2

Blood collection and storage protocol The blood from the peripheral vein will be collected in a total of 16 $\mathrm{ml}: 3$ EDTA tubes, one with $2 \mathrm{ml}$ and two with $4 \mathrm{ml}$ and 1 dry tube with separating gel. To the first EDTA tube, where $2 \mathrm{ml}$ of blood was collected, $2 \mathrm{ml}$ of RNAlater will be added for later storage. The second EDTA tube will be stored with total blood. The third EDTA tube will be centrifuged for plasma separation, along with the dry tube, for serum separation. Serum and plasma will be divided into $2 \mathrm{ml}$ aliquots and frozen at $-20^{\circ} \mathrm{C}$, together with the tube where RNAlater was added, and the EDTA tube containing whole blood. 


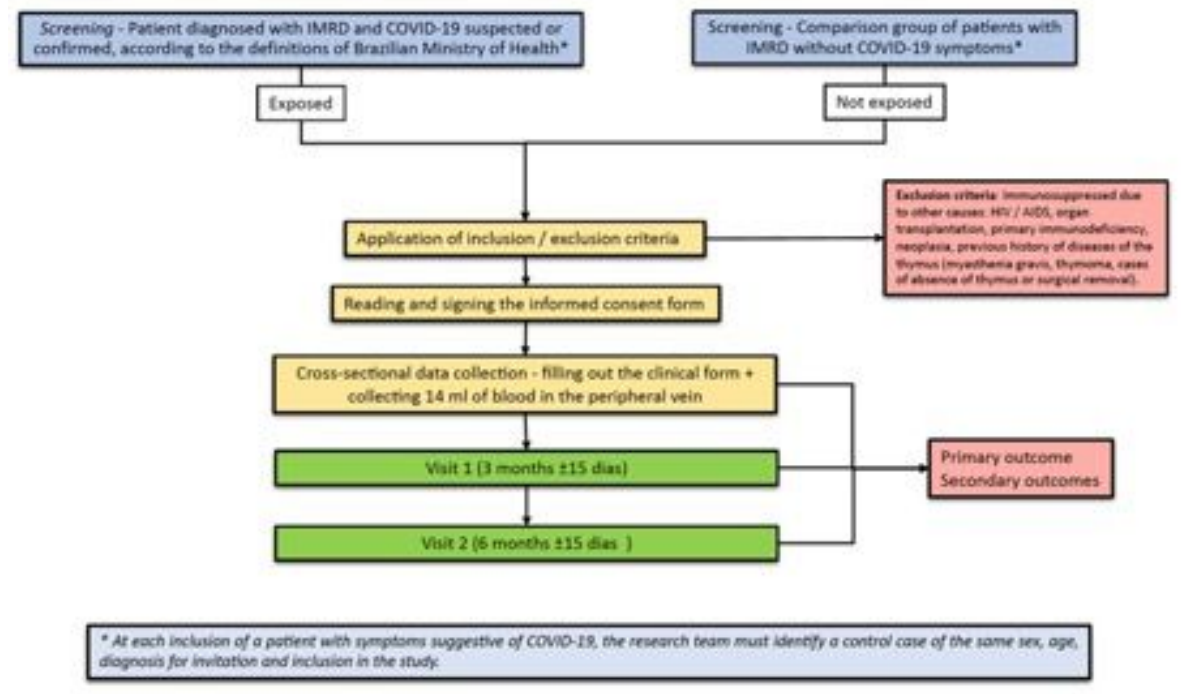

\section{Figure 3}

Study flowchart 